\title{
Unilateral congenital buphthalmos
}

\author{
George T Vasileiadis, ${ }^{1}$ Ourania Frangouli ${ }^{2}$
}

'Department of Neonatology, BHR University Hospitals NHS Trust, London, UK

${ }^{2}$ Department of

Ophthalmology, BHR University Hospitals NHS Trust, London, UK

\section{Correspondence to} Dr George T Vasileiadis, George.Vasileiadis@ bhrhospitals.nhs.uk

Accepted 12 May 2015
To cite: Vasileiadis GT Frangouli O. BMJ Case Rep Published online: [please include Day Month Year] doi:10.1136/bcr-2015210979

\section{DESCRIPTION}

A term female infant was born by forceps delivery after failed ventouse. There was a history of maternal fever and antenatal antibiotics. She was in good condition after birth but was noticed to have an 'enlarged and cloudy right eye'. Elevated $\mathrm{C}$ reactive protein led to sepsis investigations and giving the infant intravenous antibiotics. Blood culture and cerebrospinal fluid microscopy and culture were all negative. Brain MRI revealed no evidence of haemorrhage, ischaemia or space-occupying lesion.

Expert review by the ophthalmologist established the diagnosis of diffuse right corneal oedema and buphthalmos (figure 1). Clinical examination of the left eye appeared normal (figure 2). Digital and rebound tonometry with iCare showed intraocular pressure over $25 \mathrm{~mm} \mathrm{Hg}$ in the right eye and less than $15 \mathrm{~mm} \mathrm{Hg}$ in the left eye. The differential diagnosis included congenital glaucoma or anterior segment dysgenesis, but the possibility of a rare congenital corneal dystrophy or other underlying ocular pathology was also considered. Pilocarpine eye drops were introduced with good response in terms of corneal oedema and intraocular pressure. Despite the unilateral nature of the disease, the metabolic screen sent for urine amino and organic acids, galactosaemia and lysosomal neurodegenerative and storage diseases, revealed no obvious abnormalities. The infant's surgical treatment started at 2 months of age.

Buphthalmos (greek for "Ox Eye") can be the result of congenital glaucoma, and without timely

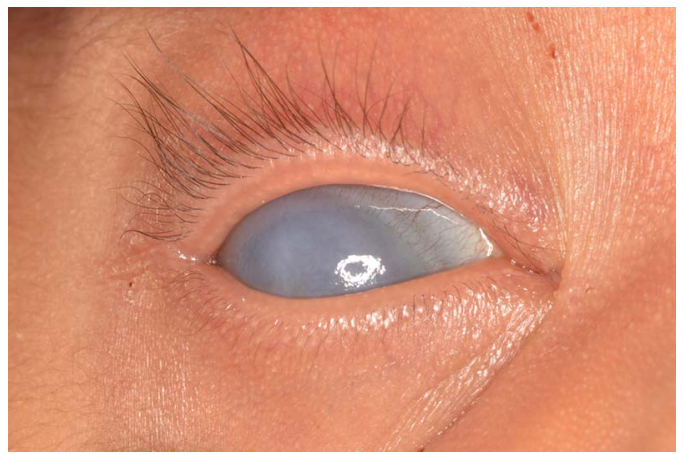

Figure 1 Diffuse right corneal oedema and buphthalmos.

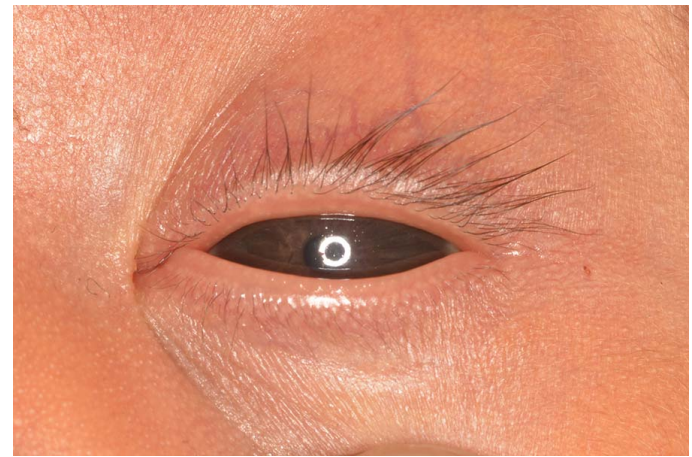

Figure 2 Normal left eye.

medical and surgical treatment may lead to seriously affected vision. ${ }^{1}$ Unilateral congenital corneal oedema may be secondary to congenital glaucoma, anterior segment dysgenesis, neurodegenerative/storage diseases, neurofibromatosis, or birth injury by forceps. ${ }^{1-3}$

\section{Learning points}

- Buphthalmos due to congenital glaucoma may be unilateral.

- The condition requires prompt review and management by senior paediatricians and ophthalmologists, and referral for surgical treatment is required in the majority of cases.

- Aetiology includes congenital abnormalities, neurometabolic diseases and trauma.

Competing interests None declared.

Patient consent Obtained.

Provenance and peer review Not commissioned; externally peer reviewed.

\section{REFERENCES}

1 Papadopoulos M, Cable N, Rahi J, et al. The British Infantile and Chilhood Glaucoma (BIG) eye study. Invest Ophthalmol Vis Sci 2007:48:4100-6.

2 Isaacs H Jr. Perinatal neurofibromatosis: two case reports and review of the literature. Am J Perinatol 2010:27:285-92.

3 Levine MG, Holroyde J, Woods JR, et al. Birth trauma: incidence and predisponding factors. Obstet Gynecol 1984;63:792-5. 


\section{Images in...}

Copyright 2015 BMJ Publishing Group. All rights reserved. For permission to reuse any of this content visit http://group.bmj.com/group/rights-licensing/permissions.

BMJ Case Report Fellows may re-use this article for personal use and teaching without any further permission.

Become a Fellow of BMJ Case Reports today and you can:

- Submit as many cases as you like

- Enjoy fast sympathetic peer review and rapid publication of accepted articles

- Access all the published articles

- Re-use any of the published material for personal use and teaching without further permission

For information on Institutional Fellowships contact consortiasales@bmjgroup.com

Visit casereports.bmj.com for more articles like this and to become a Fellow 